\title{
Improved Social Studies Learning Outcomes Through the Mind Map Method for Grade 5 SDN Ketitang
}

\section{Ika Noormaningtyas}

\author{
SD Negeri Ketitang \\ ikanoorma@gmail.com
}

\section{Article History}

received 3/12/2020

\begin{abstract}
This research is motivated by the problem of low social studies learning outcomes for grade 5 students. This is because teachers often use the lecture method, students only listen and record all information from the teacher so they consider social studies material to be difficult. This study aims to determine whether there is an increase in learning outcomes for theme 7, especially the content of social studies lessons through mind maps in grade 5 SD Negeri Ketitang, Godong District, Grobogan Regency. The research was conducted in March-April 2020 in the 5th grade of SD Negeri Ketitang, Godong District, Grobogan Regency as the research subject. The results showed that the social studies learning outcomes in the initial conditions were only $38.1 \%$ of students who reached the KKM. There was an increase in the first cycle of learning outcomes to $57.14 \%$ of students and in the second cycle increased to $85.71 \%$ of students who reached the KKM. In learning, teachers and students should more often apply the Mind Map method so that students can develop their imagination and absorption power of the material being taught.
\end{abstract}

Keywords: learning outcomes, social studies, mind map method

\begin{abstract}
Abstrak
Penelitian dilatarbelakangi oleh permasalahan rendahnya hasil belajar IPS peserta didik kelas 5. Hal ini dikarenakan guru sering menggunakan metode ceramah, peserta didik hanya mendengarkan dan mencatat semua informasi dari guru sehingga menganggap materi IPS itu sulit. Penelitian bertujuan untuk mengetahui ada tidaknya peningkatan hasil belajar tema 7 khususnya muatan pelajaran IPS melalui mind map pada kelas 5 SD Negeri Ketitang Kecamatan Godong Kabupaten Grobogan. Penelitian yang dilaksanakan pada bulan MaretApril 2020 di kelas 5 SD Negeri Ketitang Kecamatan Godong Kabupaten Grobogan sebagai subjek penelitian. Hasil penelitian menunjukkan hasil belajar IPS pada kondisi awal hanya $38,1 \%$ peserta didik yang mencapai KKM. Terjadi peningkatan pada siklus I hasil belajar menjadi $57,14 \%$ peserta didik dan pada siklus II meningkat menjadi $85,71 \%$ peserta didik yang mencapai KKM. Dalam pembelajaran sebaiknya guru dan peserta didik lebih sering menerapkan metode Mind Map agar peserta didik dapat mengembangkan daya imajinasi dan daya serapnya terhadap materi yang diajarkan.
\end{abstract}

Kata kunci: hasil belajar, IPS, metode mind map

Social, Humanities, and Education Studies (SHEs): Conference Series https://jurnal.uns.ac.id/shes

p-ISSN 2620-9284

e-ISSN 2620-9292 


\section{PENDAHULUAN}

Menurut UU RI No. 20 tahun 2003 tentang SISDIKNAS, pendidikan adalah usaha sadar dan terencana untuk mewujudkan suasana belajar dan proses pembelajaran agar peserta didik secara aktif mengembangkan potensi dirinya untuk memiliki kekuatan spiritual keagamaan, pengendalian diri, kepribadian, kecerdasan, akhlak mulia, serta keterampilan yang diperlukan dirinya, masyarakat, bangsa dan negara.

Pendidikan merupakan salah satu aspek penting yang mendorong kemajuan suatu bangsa. Bangsa yang berhasil dapat dilihat dari keberhasilan yang dicapai dari sektor pendidikan. Kemajuan pesat dalam globalisasi, mendorong suatu bangsa untuk mampu bersaing dan berkembang dalam lingkup internasional. Agar mampu bersaing tentu dibutuhkan potensi dan ketrampilan yang memadai. Maka dari itu, pendidikan di sekolah khususnya sekolah dasar tidak hanya mengajarkan berbagai mata pelajaran yang berkaitan dengan pengetahuan saja melainkan juga mengembangkan ketrampilan dan potensi yang dimiliki peserta didik.

Dari berbagai mata pelajaran yang terdapat dalam kurikulum di sekolah dasar, IPS merupakan salah satu mata pelajaran yang mencakup tentang lingkungan sosial, ilmu bumi, ekonomi, dan pemerintahan. IPS memiliki fungsi mempersiapkan peserta didik untuk menghadapi tantangan berat yang terjadi di masa depan karena kehidupan masyarakat selalu mengalami perubahan yang pesat. Oleh karena itu, mata pelajaran IPS dirancang untuk mengembangkan pengetahuan, pemahaman, dan kemampuan analisis terhadap kondisi sosial masyarakat dalam memasuki kehidupan bermasyarakat yang dinamis.

Dari hasil tanya jawab dan observasi di kelas 5 , sebagian besar peserta didik mengaku kurang paham dengan mata pelajaran IPS karena menurut mereka mata pelajaran IPS sulit. Menurut mereka, materi dalam IPS hanya berisi tulisan-tulisan yang banyak yang harus dicatat di buku dan harus dihafalkan. Sehingga banyak dari peserta didik yang mengalami kesulitan dan mengakibatkan hasil belajarnya rendah. Kebanyakan peserta didik kurang mampu menyerap materi IPS yang diajarkan walaupun guru sudah menjelaskan berkali-kali kepada peserta didik. Dari 21 peserta didik yang ada di kelas hanya beberapa anak yang mampu menjawab pertanyaanpertanyaan yang diberikan saat pelajaran IPS. Hal ini dapat terlihat dari hasil ulangan harian yaitu sebanyak 8 anak atau sebesar 38,1\% dapat mencapai nilai KKM yaitu 70 . Sedangkan 13 anak atau sebesar 61,9\% memperoleh nilai kurang dari nilai KKM yakni 70.

Ada dua faktor yang menyebabkan hasil belajar IPS peserta didik rendah, pertama dari diri peserta didik sendiri yakni peserta didik menganggap materi IPS sulit dipahami. Faktor lain yang menjadi sebab rendahnya hasil belajar peserta didik adalah faktor guru. Guru lebih memilih menggunakan metode pembelajaran yang monoton. Kebanyakan guru memilih metode pembelajaran yang sederhana yakni ceramah. Guru menjelaskan semua informasi kepada peserta didik sehingga peserta didik hanya mendengarkan, mencatatat, dan menghafalkan materi yang didapat tanpa memahami materi itu sehingga menganggap bahwa materi IPS sulit. Maka dari itu, perlu dicari alternatif metode pembelajaran yang dapat membuat peserta didik paham terhadap materi yang diberikan oleh guru.

Rendahnya pemahaman peserta didik terhadap mata pelajaran IPS tentunya menjadi persoalan yang serius jika hal ini terjadi secara terus menerus, mengingat pentingnya mata pelajaran IPS dalam dunia pendidikan. IPS sangat penting dalam dunia pendidikan, tidak hanya sebatas untuk memenuhi kurikulum sekolah tetapi di dalam mata pelajaran IPS terkandung materi dan nilai yang akan membantu peserta didik untuk berinteraksi dan hidup di tengah masyarakat.

Salah satu metode alternatif yang dapat digunakan adalah metode pembelajaran Mind Map. Mind Map merupakan metode pembelajaran yang pertama kali diperkenalkan oleh Tony Buzan. Menurutnya, Mind Map adalah cara mudah menggali 
informasi dari luar maupun dari dalam otak (Tony Buzan, 2012:4). Mind Map merupakan metode pembelajaran yang efektif untuk mengembangkan gagasangagasan melalui rangkaian peta-peta (Miftahul Huda, 2013:307). Mengembangkan gagasan-gagasan melalui rangkaian peta-peta pikiran maksudnya ialah peserta didik tidak perlu menuliskan semua informasi yang diperoleh dengan cara membuat catatan yang begitu banyak, sehingga menghabiskan banyak lembar dan kurang efisien. Peserta didik hanya perlu menuliskan pokok informasi yang diperoleh. Kemudian informasi pokok yang didapat dihubungkan dengan setiap informasi yang didapat peserta didik dengan informasi lain dalam selembar kertas. Dengan metode ini, peserta didik dapat menggambarkan alur pemikirannya masing-masing sesuai dengan informasi yang telah didapat.

Peneliti memilih metode pembelajaran Mind Map karena menurut Tony Buzan (Miftahul Huda, 2013: 307), Mind Map bisa digunakan untuk membantu penulisan esai atau tugas-tugas yang berkaitan dengan penguasaan konsep. Pada hakikatnya, Mind Map digunakan untuk membrainstorming suatu topik sekaligus menjadi strategi ampuh bagi belajar peserta didik. Mind Map sangat ideal untuk melejitkan pemikiran peserta didik.

Keberhasilan metode pembelajaran sudah dibuktikan oleh Asrori tahun 2014 dalam "Upaya Meningkatkan Hasil belajar IPS Melalui Metode Mind Map pada Peserta didik Kelas $5 \mathrm{MI}$ Muhammadiyah Jambukidul Ceper Klaten Tahun Pelajaran 2013/2014". Hasil penelitian menunjukkan bahwa Mind Map meningkatkan hasil belajar peserta didik dari kondisi awal hanya sebanyak $17 \%$ peserta didik yang mencapai KKM, kemudian setelah diberi tindakan perbaikan pada siklus I peserta didik yang mencapai KKM meningkat menjadi 50\%. Sedangkan pada siklus II seluruh peserta didik atau dengan presentase $100 \%$ mencapai nilai KKM.

Berdasarkan latar belakang, maka peneliti merumuskan masalah penelitian yaitu apakah terjadi peningkatan hasil belajar tema 7 subtema 1 mupel IPS melalui metode pembelajaran Mind Map kelas 5 SD Negeri Ketitang Kecamatan Godong Kabupaten Grobogan Semester II Tahun Pelajaran 2019/2020 dan seberapa besar peningkatan hasil belajar peserta didik pada mata pelajaran IPS melalui metode Mind Map peserta didik kelas 5 SD Negeri Ketitang Kecamatan Godong Kabupaten Grobogan Semester II Tahun Pelajaran 2019/2020.

Tujuan penelitian ini adalah untuk mengetahui peningkatan hasil belajar pada mata pelajaran IPS melalui metode pembelajaran Mind Map peserta didik kelas 5 SD Negeri Ketitang Kecamatan Godong Kabupaten Grobogan Semester II Tahun Pelajaran 2019/2020 dan besar peningkatan hasil belajar peserta didik pada tema 7 subtema 1 muatan pelajaran IPS melalui metode Mind Map peserta didik kelas 5 SD Negeri Ketitang Kecamatan Godong Kabupaten Grobogan Semester II Tahun Pelajaran 2019/2020.

\section{METODE}

Jenis penelitian yang dilakukan merupakan Penelitian Tindakan Kelas (PTK) atau Classroom Action Research (CAR). Tindakan tersebut dilakukan oleh guru atau dengan arahan dari guru yang dilakukan oleh peserta didik (Arikunto, 2012:3). Penelitian Tindakan Kelas ini akan dilaksanakan di kelas 5 SD Negeri Ketitang Kecamatan Godong Kabupaten Grobogan Semester II Tahun Pelajaran 2019/2020. Penelitian dilaksanakan selama 2 bulan yaitu dari bulan Maret sampai dengan bulan April 2020.

Subyek penelitian yaitu peserta didik kelas 5 SD Negeri Ketitang, yang beralamat di Jalan Kemetiran No.1 Desa Ketitang Kecamatan Godong Kabupaten Grobogan. Peserta didik kelas 5 SD Negeri Ketitang memiliki hasil belajar yang rendah pada mata pelajaran IPS. Peserta didik kelas 5 berjumlah 21 peserta didik yang terbagi menjadi 14 peserta didik laki-laki dan 7 peserta didik perempuan. 
Penelitian ini menggunakan model Kemmis yang dikembangkan oleh Stephen Kemmis dan Roin Mc Taggart. Model ini meliputi tahapan perencanaan (planning), tindakan (action) dan observasi (observation), dan refleksi (reflection) yang saling terkait satu sama lain. Kemudian diikuti dengan perencanaan ulang yang dilaksanakan dalam bentuk siklus tersendiri (Zainal, 2011:22). Teknik pengumpulan data dilakukan dengan cara observasi (dilakukan selama proses pembelajaran), tes (dilaksanakan pada akhir pembelajaran setiap siklus), dan dokumentasi (melihat situasi pada saat proses pembelajaran) (Sugiyono, 2013: 329).

\section{HASIL DAN PEMBAHASAN}

Menurut Kamus Besar Bahasa Indonesia, Kata "hasil" berarti sesuatu yang terjadi karena usaha. Sedangkan "belajar" memiliki makna berusaha memperoleh kepandaian atau ilmu. Dari pengertian tersebut dapat dijelaskan bahwa hasil belajar merupakan suatu kepandaian atau ilmu yang diperoleh dengan suatu usaha yaitu proses pembelajaran.

Untuk mencapai hasil belajar yang optimal perlu diciptakan suasana belajar yang kondusif, maka perlu memperhatikan faktor-faktor yang mempengaruhi hasil belajar peserta didik. Menurut Slameto (2010: 54) faktor-faktor yang mempengaruhi hasil belajar digolongkan menjadi dua.

Faktor internal adalah faktor yang berasal dari diri peserta didik, misalnya factor jasmaniah (kesehatan dan cacat tubuh), faktor psikologis (intelegensi, minat, perhatian, bakat motif, dan kematangan) dan faktor kelelahan (kelelahan jasmani dan kelelahan rohani). Faktor eksternal adalah faktor yang berasal dari luar diri peserta didik, misalnya faktor keluarga (cara mendidik orang tua, relasi antar anggota keluarga, suasana rumah, keadaan ekonomi, pengertian orang tua, dan latar belakang kebudayaan), faktor sekolah (metode mengajar, relasi guru dan peserta didik, relasi peserta didik dengan peserta didik, disilpin sekolah, alat pengajaran, waktu sekolah, standar pelajaran di atas ukuran, keadaan gedung, metode belajar dan tugas rumah), dan faktor masyarakat (keadaan peserta didik dalam masyarakat, media massa, teman bergaul, dan bentuk kehidupan masyarakat).

Dari penjelasan di atas, dapat dilihat bahwa faktor-faktor yang mempengaruhi hasil belajar berasal dari faktor internal dan faktor eksternal. Pada penelitian ini menggunakan faktor eksternal berupa penggunaan metode pembelajaran Mind Map pada kelas 5 dalam pembelajaran tema 7 subtema 1 mupel IPS.

Penelitian berfokus pada perbaikan untuk meningkatkan hasil belajar IPS khususnya pada aspek kognitif, peserta didik kelas 5 SD Negeri Ketitang dengan menggunakan metode pembelajaran Mind Map. Metode pembelajaran ini membantu peserta didik untuk mengembangkan imajinasi dan daya pikir peserta didik dalam belajar, sehingga peserta didik lebih mudah dalam memahami materi pelajaran yang diperoleh dari guru. Tugas guru dalam pembelajaran ialah sebagai fasilitator, yakni memfasilitasi peserta didik dalam proses pembelajaran.

Dalam pembelajaran dengan menggunakan metode pembelajaran Mind Map, peserta didik menerima materi yang disampaikan oleh guru dalam bentuk peta pikiran yang berisi konsep-konsep kunci materi. Kemudian peserta didik membuat dan mengembangkan daya pikir mereka dengan membuat peta pikiran mereka sendiri di dalam suatu kelompok. Para peserta didik berdiskusi dan bekerja sama untuk membuat catatan sendiri. Setelah peserta didik selesai membuat catatan sendiri, hasil pekerjaan dipresentasikan di depan kelas secara bergantian tiap kelompok. Pada akhir pembelajaran guru memberikan evaluasi untuk mengetahui tingkat pemahaman peserta didik terhadap materi yang telah diajarkan. Pembelajaran dengan menggunakan metode Mind Map ini menjadikan peserta didik senang dalam mengikuti pembelajaran. Peserta didik menjadi mudah memahami materi karena tidak perlu mencatat dengan kalimat-kalimat yang panjang dan menghapalkannya nanti, tetapi 
hanya menuliskan dengan peta pikiran yang dibuat sendiri berisi konsep-konsep kunci materi yang didapatkan. Hal ini tentunya memberikan pengaruh dalam perbaikan upaya peningkatan hasil belajar IPS peserta didik.

Proses pembelajaran dengan menerapkan metode Mind Map dalam penelitian tindakan kelas ini, dilakukan dengan menyajikan Mind Map dalam langkah-langkah pembelajaran yakni kegiatan pendahuluan, kegiatan inti, dan penutup. Guru melakukan kegiatan eksplorasi dengan memberi kesempatan peserta didik menggali informasi, melalui kegiatan membaca teks materi yang ada. Kemudian, guru memberi kesempatan dan mengawasi peserta didik melakukan diskusi kelompok dalam mengerjakan tugas kelompok yang telah diberikan oleh guru, yang kemudian hasil diskusi mereka dipresentasikan pada akhir pembelajaran. Kemudian guru memanggil perwakilan setiap kelompok mempresentasikan hasil pekerjaan kelompok di depan kelas secara bergantian. Guru memberi konfirmasi pada setiap presentasi peserta didik dan memberi motivasi peserta didik untuk belajar dan bekerja sama dengan baik.

Tabel 1. Perbandingan Ketuntasan Hasil Belajar IPS Peserta didik Kondisi Awal, Siklus I, dan Siklus II

\begin{tabular}{|c|c|c|c|c|c|c|c|}
\hline \multirow[b]{2}{*}{ No } & \multirow[b]{2}{*}{ Nilai } & \multicolumn{2}{|c|}{ Kondisi Awal } & \multicolumn{2}{|c|}{ Siklus I } & \multicolumn{2}{|c|}{ Siklus II } \\
\hline & & $\begin{array}{c}\text { Jumlah } \\
\text { Peserta } \\
\text { didik }\end{array}$ & $\begin{array}{c}\text { Prosentase } \\
(\%)\end{array}$ & $\begin{array}{c}\text { Jumlah } \\
\text { Peserta } \\
\text { didik }\end{array}$ & $\begin{array}{c}\text { Prosentase } \\
(\%)\end{array}$ & $\begin{array}{c}\text { Jumlah } \\
\text { Peserta } \\
\text { didik }\end{array}$ & $\begin{array}{c}\text { Prosentase } \\
(\%)\end{array}$ \\
\hline 1 & $<70$ & 13 & 61,9 & 9 & 42,86 & 3 & 14,29 \\
\hline 2 & $\geq 70$ & 8 & 38,1 & 12 & 57,14 & 18 & 85,71 \\
\hline \multicolumn{2}{|c|}{ Jumlah } & 21 & 100 & 21 & 100 & 21 & 100 \\
\hline
\end{tabular}

Berdasarkan tabel di atas dapat dilihat bahwa pada kondisi awal yang tuntas hasil belajar hanya 8 peserta didik atau sebesar $38,1 \%$ dan yang belum tuntas sebanyak 13 peserta didik atau sebesar $61,9 \%$ dengan nilai rata-rata 60,95. Pada siklus I terjadi peningkatan menjadi 12 peserta didik atau sebesar 57,14\% dari 21 peserta didik yang mencapai ketuntasan nilai KKM 70 dan sebanyak 9 peserta didik atau sebesar $42,86 \%$ peserta didik belum mencapai nilai KKM 70 dengan nilai rata-rata 69,62 . Peserta didik yang sudah tuntas diberikan pengayaan, sedangkan yang belum tuntas diberi remidial. Peningkatan yang terjadi sebesar 19,04\%. Meskipun demikian, peningkatan hasil belajar ini belum mencapai kriteria yang ditetapkan peneliti yaitu $85 \%$ dari jumlah peserta didik.

Perolehan hasil belajar peserta didik pada siklus I sudah menunjukan adanya peningkatan, dengan ketuntasan klasikal yang mencapai $57,14 \%$ dan perolehan nilai rata-rata 69,62. Hal ini menunjukan bahwa penelitian tindakan siklus I belum berhasil. Kerjasama antar peserta didik juga sudah nyata dalam diskusi kelompok membuat peta pikiran. Penelitian dilanjutkan ke siklus II dengan memperbaiki dan lebih mengoptimalkan pembelajaran sesuai dengan hasil refleksi. Perbaikan tersebut diantaranya guru lebih memberikan bimbingan kepada peserta didik selama langkahlangkah pembelajaran, peserta didik lebih diarahkan untuk memperhatikan peserta didik yang sedang melakukan presentasi dan meminta untuk memberikan komentar terhadap hasil presentasi tersebut, dan guru memberikan reward/penguatan kepada peserta didik yang menjawab dengan benar baik secara individu maupun kelompok.

Kondisi ini berubah setelah dilakukan tindakan pada Siklus II, yakni peserta didik yang memperoleh nilai di bawah KKM sebanyak 3 peserta didik atau sebesar 14,29\% dan peserta didik yang berhasil lulus KKM sebanyak 18 peserta didik atau sebesar $85,71 \%$. Peserta didik yang sudah tuntas diberikan pengayaan, sedangkan yang belum tuntas diberi remidial. 
Dari pengamatan terhadap proses pembelajaran yang terjadi pada tindakan siklus II, peserta didik sudah lebih paham dalam mengikuti langkah-langkah pembelajaran dengan metode Mind Map. Hasil ketuntasan belajar 21 peserta didik pada siklus II meningkat lagi menjadi $85,71 \%$. Dapat dikatakan bahwa peserta didik telah mencapai ketuntasan belajar sebab telah memenuhi standart ketuntasan belajar $85 \%$. Sampai pada perbaikan pembelajaran siklus II, hanya tiga peserta didik saja yang belum mencapai nilai tuntas.

Adanya peningkatan pada hasil belajar IPS peserta didik. Pada kondisi awal, peserta didik yang mencapai ketuntasan hanya sebesar $38,1 \%$, pada siklus I peserta didik yang mencapai ketuntasan sebesar $57,14 \%$, dan pada siklus II peserta didik yang mencapai ketuntasan sebanyak sebesar $85,71 \%$. Terjadi peningkatan sebesar $19,04 \%$ pada siklus I dari kondisi awal dan peningkatan sebesar $28,57 \%$ pada siklus II dari siklus I. Sedangkan peningkatan yang terjadi dari kondisi awal ke siklus II sebesar $47,61 \%$. Peningkatan hasil belajar ini sudah mencapai kriteria yang ditetapkan peneliti yaitu $85 \%$ dari jumlah peserta didik.

Hasil penelitian tindakan kelas ini, juga sejalan dengan penelitian yang telah dilaksanakan oleh Asrori (2014:69), menyatakan "hasil belajar IPS siwa kelas 5 MI Muhammadiyah Jambukidul setelah menggunakan metode Mind Map meningkat. Berdasarkan hasil ini bahwa dengan menerapkan metode pembelajaran Mind Map, hasil belajar peserta didik pada mata pelajaran IPS materi pokok perjuangan mempertahankan kemerdekaan pada masa awal kemerdekaan di kelas $5 \mathrm{Ml}$ Muhammadiyah Jambukidul Ceper Klaten meningkat dan berhasil". Berdasarkan pada hasil penelitian yang dilakukan penulis dalam menerapkan Mind Map dalam pembelajaran tema 7 subtema 1 mupel IPS di SD Negeri Ketitang menunjukkan bahwa dengan menerapkan metode pembelajaran Mind Map, dapat meningkatkan hasil belajar peserta didik kelas 5 SD Negeri Ketitang pada mata pelajaran IPS Semester II Tahun Pelajaran 2019/2020.

Hal ini dapat membuktikan bahwa metode pembelajaran Mind Map dapat meningkatkan hasil belajar IPS khususnya pada aspek kognitif peserta didik kelas 5 SD Negeri Ketitang Kecamatan Godong Kabupaten Grobogan. Metode Mind Map membuat peserta didik lebih baik dalam memahami materi pembelajaran karena peserta didik mengatur sendiri bagaimana mereka ingin mencatat atau menggambarkan materinya, sehingga membuat nilai yang lebih bagus.

\section{SIMPULAN}

Setelah dilakukan tindakan dapat disimpulkan bahwa penerapan metode Mind Map dapat meningkatkan hasil belajar IPS. Peningkatan hasil belajar IPS peserta didik dari kondisi awal sebelum dilakukan tindakan hingga siklus II yakni sebesar 47,61\%. Alasan penggunaan metode pembelajran Mind Map pada mata pelajaran IPS yaitu melalui langkah-langkah Mind Map peserta didik dituntut untuk berkreasi dan berpikir secara aktif dengan menggunakan fungsi kerja kedua otak kanan dan kiri secara seimbang. Maka kemampuan belajar peserta didik meningkat dan memiliki kemampuan untuk mengingat serta memahami materi dengan lebih baik, sehingga hasil belajar peserta didik pun meningkat.

Implikasi teoritis penelitian ini yaitu dapat dijadikan sebagai perbaikan metode pembelajaran di sekolah tentang pengembangan metode pembelajaran Mind Map, sebagai metode untuk meningkatkan hasil belajar peserta didik dalam belajar. Selain itu, dapat dijadikan sebagai dasar bertindak bagi pendidik dan dunia kependidikan pada umumnya.

Implikasi praktis yang diperoleh dari penelitian ini bagi guru/peneliti, sebagai tambahan pengetahuan mengenai metode pembelajaran Mind Map dan mengembangkan proses pembelajaran di kelas. Bagi peserta didik, dengan Mind Map dapat mempermudah mempelajari materi pelajaran dan meningatkan daya ingat 
peserta didik. Sedangkan bagi sekolah, sebagai bahan masukan kepustakaan sekolah dan tambahan karya guru, serta memberikan wawasan mengenai metode yang cocok untuk meningkatkan hasil belajar peserta didik.

\section{DAFTAR PUSTAKA}

Arikunto, S. 2012. Penelitian Tindakan Kelas. Jakarta: Bumi Aksara

Aqib, Z. 2011. Penelitian Tindakan Kelas Bandung: Yrama Widya

Asrori. 2014. Upaya Meningkatkan Hasil belajar IPS Melalui Metode Mind Map pada Peserta didik Kelas 5 MI Muhammadiyah Jambukidul Ceper Klaten Tahun Pelajaran 2013/2014. Skripsi. Yogyakarta: FKIP-UIN Sunan Kalijaga

Buzan, T. 2012. Buku Pintar Mind Map. Jakarta: Gramedia

Huda, Miftahul. 2013. Model-model Pengajaran dan Pembelajaran. Malang: Pustaka Pelajar.

Nurhasanah, dkk. 2013. Kamus Besar Bergambar Bahasa Indonesia. Jakarta: PT. Bina Sarana Pustaka

Slameto. 2010. Belajar dan Faktor-faktor yang Mempengaruhinya. Jakarta: Rineka Cipta

Sugiyono. 2013. Metode Penelitian Pendidikan. Bandung: Alfabeta

Syamsuddin, A. 2012. Pengertian, fungsi dan tujuan pembelajaran IPS. http://pgmionemode.blogspot.com, diakses pada tanggal 9 Maret 2020 jam 15:00

UU RI No. 20 tahun 2003 tentang Sistem Pendidikan Nasional. Jakarta: Dikti 